\title{
CLINICAL AND IMMUNOLOGICAL CHARACTERISTICS OF CATS AFFECTED BY FELINE INFECTIOUS PERITONITIS
}

\author{
Z . KNOTEK ${ }^{1}$, M. TOMAN ${ }^{2}$, M. FALDYNA ${ }^{2}$ \\ ${ }^{1}$ University of Veterinary and Pharmaceutical Sciences, Brno, Czech Republic \\ ${ }^{2}$ Veterinary Research Institute, Brno, Czech Republic \\ Received November 11, 1999 \\ Accepted February 17, 2000
}

Abstract

Knotek Z., M. Toman, M. Faldyna: Clinical and Immunological Characteristics of Cats Affected by Feline Infectious Peritonitis. Acta Vet. Brno 2000, 69: 51-60.

A set of 180 hospitalized or outdoor feline patients was examined for the presence of antibodies to feline coronavirus (FeCoV) and clinical signs of feline infectious peritonitis (FIP). The numbers of serologically and clinically positive cats were $55(30.6 \%)$ and 35, respectively. The effusive and noneffusive forms of FIP were diagnosed in 24 and 11 animals, respectively. The most apparent signs, irrespective of the form of infection, included anorexia, lethargy, ischemic mucosae, and undernutrition. Hematological and immunological profiles of 14 FIP patients were compared with those found in a control group of 36 clinically normal and $\mathrm{FeCoV}$-negative animals. A significant increase in the number of neutrophilic granulocytes was observed in the FIP patients (FIV-/FeLVcats with effusive form) and a significant decrease in the number of lymphocytes were observed in the FIP patients. Eosinopenia was also found in patients affected by the effusive form. No alteration of the phagocytic activity (ingestion of particles, chemiluminiscence) due to FIP was demonstrable. The blastic transformation test (stimulation with Con A, PHA, or PWM) showed a marked decrease in the activity of lymphocytes in the FIP patients. Concentrations of immunoglobulins and circulating immune complexes were increased in the affected animals. The expression of the lymphocyte surface antigens CD4, CD5, CD8, and CD21 was studied in a selected subgroup of the patients using flow cytometry. The results indicate an impairment of the activity of the immune system due to FIP. Therefore, treatment of FIP with immunosuppressive drugs is considered inappropriate.

Coronavirus infection, immune complexes, blastic transformation of lymphocytes, feline CD antigens

Feline infectious peritonitis (FIP) is a very serious viral disease affecting particularly younger cats. The first description of this infection was published in 1966 (Wolfe and Griesemer 1966). The causative agent (FIPV) is a feline coronavirus (FeCoV) which is responsible also for the noneffusive form characterized by pyogranulomatous lesions and in some cases also by meningoencephalitis and panophthalmitis (Hoskins et al. 1994; Weis s 1994; Pedersen 1995). FeCoV are known for their considerable variability. It has been demonstrated that FIP can develop as a result of mutation of $\mathrm{FeCoV}$ in the intestine of cats affected by coronavirus-induced enteritis (Evermann et al. 1991). Outbreaks of FIP can occur also in colonies where not a single case was recorded in the past. The highest losses are observed in cat homes and breeding colonies (Weiss 1994). Critical in the pathogenesis of FIP is the function of the system of cell-mediated immunity (Pedersen 1995) that can either prevent, or allow full development of clinical disease in infected animals. The patient can develop latent infection and become a virus carrier in the first case (Weiss 1994). Breakthrough of immunity results from impaired collaboration of Tlymphocytes with FIP-infected macrophages. It is evident that stress or immunosuppression play an important role in the onset of FIPV viremia (Weis s 1994). Immune complexes of FIPV with antibodies bind, through Fc fragments and in the presence of complement, with

Address for correspondence: Doc. MVDr. Zdeněk Knotek, CSc. Small Animal Clinic

armaceutical Sciences

Palackého 1-3, 61242 Brno, Czech Republic
Phone: +42541562382

Fax: +42 541562382

http://www.vfu.cz/acta-vet/actavet.htm 
macrophages (Olsen 1993). Macrophages are involved in the immunopathogenesis of FIP, in particular in the development of perivascular lesions, by release of inflammatory mediators including the C3 protein of complement, C5 protein, leukotriene B4, prostaglandins, and interleukins IL-1 and IL-6. The mediators activate B-lymphocytes and induce fever and hypergammaglobulinemia (Weis s 1994). The host immune system can partially limit the inflammatory reaction in noneffusive forms. In such cases, pyogranulomatous lesions develop in various organs, on the omentum and on serous membranes. Results of immunohistological analyses and detailed examination of blood proteins indicate that the pathogenesis of FIP corresponds, to a considerable extent, to the

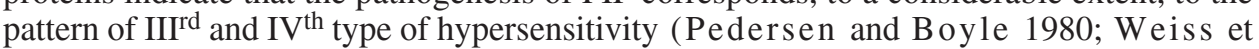
al. 1980; Pedersen 1987; Paltrinieri et al. 1998b).

Although corticoids have been recommended for the treatment of FIP, the efficacy of immunosuppressive drugs may be questionable. Moreover, adverse effects of long-term administration of such drugs to cats must be considered (Weis s 1994).

The aim of our investigations was to assess the prevalence of cats positive for antibodies to $\mathrm{FeCoV}$ in the Moravian region of the Czech Republic, and to examine immunological profiles of those showing clinical signs of FIP.

\section{Materials and Methods}

Animals and sampling

We performed our study on 180 cats, of which 153 were hospitalized at the Small Animal Clinic of the Faculty of Veterinary Medicine, Brno, and 27 were outdoor patients of the clinic. Comprehensive immunological examination was done in 14 patients showing clinical manifestations of FIP. Total and differential leukocyte counts and immunological profiles were simultaneously examined in a set of 36 clinically normal cats free from FeLV, FIV and $\mathrm{FeCoV}$ infections.

Blood samples for hematological examinations, collected from vena cephalica, were preserved with chelaton. Those intended for biochemical and immunological examinations were collected from the same site into plastic test tubes containing sodium heparin (Heparin $15 \mathrm{IE}$ per $1 \mathrm{ml}$ ). Blood serum for the determination of total concentrations of immunoglobulin and circulating immune complexes was prepared from separately collected samples.

Effusions for cytological examinations and electrophoretic separation of proteins were collected by abdominocenthesis or thoracocenthesis and kept in test tubes containing chelaton and heparin, respectively.

Diagnostics of feline infectious peritonitis

Patients suspected of clinical FIP were examined using a protocol allowing the assessment of the combination of anamnestic data and clinical and laboratory findings (Rohrer et al. 1993). The commercial ELISA kit DiaSystems ${ }^{\circledR}$ CELISA-FIP (IDEXX Laboratories, Inc., USA), demonstrating antibodies to envelope antigens of FeCoV, was used for serological examinations.

Demonstration of FeLV antigen and antibodies to FIV

The commercial kits Witness FIV and Witness FeLV (Merial, France) were used for the demonstration of antibodies to FIV and FeLV antigen, respectively. The tests are based on rapid immunomigration and detect antibodies to gp 40 FIV and the major core antigen p 27 FeLV, respectively. Fresh noncoagulated blood or frozen blood plasma or serum samples collected from 134 male and 46 female cats were tested. The same set of samples was also tested using ELISA kits (PetChek FeLV and PetChek FIV, IDEXX) detecting antibodies to p 24 FIV and antigen p $27 \mathrm{FeLV}$, respectively. The results obtained by the use of these tests are not published in the present paper.

Immunological profiles of selected patients

Complete leukocyte counts were determined using the Digicell 500 cell counter (Contraves AG, Switzerland). Differential leukocyte counts were enumerated from blood smears stained with May-Grünwald and GiemsaRomanowski. Phagocytosis by neutrophils and monocytes of metacrylate particles was assessed in whole blood using a modification of the test described by Větvička et al. (1982). Fifty $\mu 1$ suspension of MSHP particles (ARTIM, Prague) was mixed with $100 \mu \mathrm{l}$ blood in an Eppendorf-type test tube and incubated at $37^{\circ} \mathrm{C}$ for 1 hour adding $20 \mu \mathrm{l} \mathrm{Na}$ EDTA $\left(10^{-4} \mathrm{M}\right) 5 \mathrm{~min}$ before the end of the incubation. Blood smears were prepared and stained with Giemsa-Romanowski thereafter. At least 200 cells were examined in each smear to determine the proportions of the individual leukocyte types and the percentage of phagocytizing cells, i.e. those in which at least 3 particles were engulfed. 
The metabolic activity of neutrophils and monocytes was expressed in terms of chemiluminiscence after reaction with luminol. "Resting" cells (spontaneous chemiluminiscence) and cells stimulated with rice starch (activated chemiluminiscence) were tested. One hundred $\mu$ l blood was diluted with $400 \mu$ MEM medium, $\mathrm{pH}$ 7.4. Two hundred $\mu \mathrm{l}$ luminol $\left(10^{-4} \mathrm{M}\right)$ was added to all the samples and $1 \%$ rice starch solution was added to selected samples immediately before measuring. The samples were measured with the BioOrbit 1251 luminometer in duplicates at 2-min intervals for $20 \mathrm{~min}$. The highest value recorded during this period was taken as the peak of the metabolic activity. The respiratory burst index was defined as the ratio between the peaks of the spontaneous and the activated chemiluminiscences.

The activity of concanavalin A-stimulated lymphocytes was tested in whole blood using the lymphocyte transformation test. Blood samples were diluted 1:10 with the RPMI 1640 medium (Sigma, St. Louis). Two hundred $\mu 1$ diluted blood was pipetted into microtitre plate wells in triplicates. Then $20 \mu 1$ mitogen (PHA $40 \mu \mathrm{g} / \mathrm{ml}$, Con A $10 \mu \mathrm{g} / \mathrm{ml}$, or PWM $10 \mu \mathrm{g} / \mathrm{l}$ ) was added to each well. The mitogens were used at their optimal concentrations, i.e. those giving maximum counts per min in pilot testing. The microplates were incubated at $37{ }^{\circ} \mathrm{C}$ for 3 days with ${ }^{3} \mathrm{H}$-thymidine labeling during the last 20 hours. The incorporation of ${ }^{3} \mathrm{H}$-thymidine was measured using a liquid scintillation counter (Packard Tricarb CA 600, Canberra, Packard). The results were expressed in terms of stimulation indices calculated as the ratio between the activities of stimulated and nonstimulated cells.

Lymphocyte subsets were enumerated by flow cytometry using the indirect whole blood lysis technique as described elsewhere (Faldyna and Toman 1998). Briefly: fifty $\mu$ l blood was incubated with monoclonal antibody at room temperature for $15 \mathrm{~min}$. After hemolysis, centrifugation and removal of the supernatant, second antibody was added and the suspension was incubated at $4{ }^{\circ} \mathrm{C}$ for $20 \mathrm{~min}$. The cells were washed and centrifuged and the sediment was resuspended in the washing solution. The enumeration was done using the flow cytometer FACSCalibur (Becton Dickinson, Mountain View, CA, USA). The murine anti-feline monoclonal antibodies CD4 (FE.17B12), CD5 (FE1.1B11), CD8 $\alpha$ (FE1.10E9), and CD 21 (FE2.9F6), kindly supplied by Professor P. Moore (Davis, CA, USA), were used as the primary antibodies, and fluorescein isothiocyanate-labeled porcine anti-mouse immunoglobulin (SwAM-FITC, SEVAC, Prague) as the second antibody.

The total immunoglobulin concentration was determined spectrophotometrically by measurement of turbidity resulting from the addition of zinc sulphate to blood serum. The procedure was a modification of the method described by McEwan et al. (1970). Twenty - five $\mu$ l blood serum was mixed with $1.3 \mathrm{ml} 0.7 \mathrm{mM}$ zinc sulphate, $\mathrm{pH} 5.8$, and the resulting turbidity was measured at $590 \mathrm{~nm}$ after $2 \mathrm{~h}$ at room temperature. A blank was run with each blood serum sample. The concentrations of immunoglobulins were calculated from calibration curves for standards with different Ig concentrations.

The concentrations of circulating immune complexes (CIC) in blood serum samples were determined using nephelometric measurement of soluble antigen-antibody complexes after their precipitation with polyethylene glycol (PEG, Hašková 1986). Stock solution was prepared by completing 41.66 g PGE 600 (Serva) to $1000 \mathrm{ml}$ with borate buffer, $\mathrm{pH}$ 8.4. The tested sera were prediluted 1:2 with PBS and mixed at the ratio 1:9 with the PGE stock solution in one test tube and with PBS in another test tube. Turbidity was read at $450 \mathrm{~nm}$ using the spectrophotometer Spekol 11 (Carl Zeiss, Jena, Germany) after $60 \mathrm{~min}$ incubation at $22^{\circ} \mathrm{C}$. CIC was expressed in terms of difference between absorbances in the two test tubes multiplied by 1000 .

The immunological data were evaluated using Student's $t$-test.

\section{Results}

\section{Presence of antibodies to FeCoV and clinical manifestation of FIP}

Antibodies to coronaviruses were found in blood sera of $55(30.6 \%)$ of the 180 cats. Characteristics of the group of the patients positive for antibodies to $\mathrm{FeCoV}$ are given in Table 1. Serologically positive for FeLV antigen and for antibodies to FIV were $23(12.8 \%)$ and $10(5.6 \%)$ of the 180 cats, respectively. Two cats $(1.1 \%)$ were positive for both FeLV and FIV.

Clinical signs were observed in 35 patients (Table 2). The diagnosis of FIP was based on findings of nonregenerative anemia, hyperproteinemia, alteration of AST activity, characteristic electrophoretic patterns of blood serum proteins, and post mortem findings. The effusions were sterile and contained large amounts of proteins (>50 g/l). Twenty of the serologically positive animals were free from clinical signs.

Immunological indices in cats showing clinical FIP

In the group of cats showing clinical signs of FIP fourteen were examined using a battery of hematological and immunological methods. Six of them suffered from effusive infectious peritonitis, characterized particularly by abdominal distention, anorexia and fever, and four 
Table 1

Characteristics of cats positive for antibodies to coronaviruses $(n=55)$

\begin{tabular}{|c|c|c|c|c|c|}
\hline \multicolumn{2}{|c|}{ Parameter } & $\begin{array}{c}\text { FeLV- /FIV- } \\
n=45\end{array}$ & $\begin{array}{c}\text { FeLV+ / FIV- } \\
n=5\end{array}$ & $\begin{array}{c}\text { FeLV-/FIV+ } \\
n=4\end{array}$ & $\begin{array}{c}\text { FeLV+/ FIV+ } \\
n=1\end{array}$ \\
\hline Breed & $\begin{array}{l}\text { Local Shorthaired } \\
\text { Persian } \\
\text { Siamese } \\
\text { British Shorthaired } \\
\text { Russian Blue }\end{array}$ & $\begin{array}{r}25 \\
14 \\
5 \\
1 \\
-\end{array}$ & $\begin{array}{l}3 \\
1 \\
- \\
- \\
1\end{array}$ & $\begin{array}{l}2 \\
- \\
1 \\
- \\
1\end{array}$ & $\begin{array}{l}1 \\
- \\
- \\
- \\
-\end{array}$ \\
\hline Movement & $\begin{array}{l}\text { Free, unlimited } \\
\text { Limited }\end{array}$ & $\begin{array}{l}32 \\
13\end{array}$ & $\begin{array}{l}3 \\
2\end{array}$ & $\begin{array}{l}3 \\
1\end{array}$ & $\begin{array}{l}1 \\
-\end{array}$ \\
\hline Sex & $\begin{array}{l}\text { Intact males } \\
\text { Castrated males } \\
\text { Intact females } \\
\text { Castrated females }\end{array}$ & $\begin{array}{r}23 \\
8 \\
11 \\
3 \\
\end{array}$ & $\begin{array}{l}1 \\
3 \\
- \\
1\end{array}$ & $\begin{array}{l}3 \\
- \\
1 \\
-\end{array}$ & $\begin{array}{l}1 \\
- \\
- \\
-\end{array}$ \\
\hline Age & $\begin{array}{l}<1 \text { year } \\
1 \text { to } 4 \text { years } \\
>4 \text { years }\end{array}$ & $\begin{array}{r}6 \\
33 \\
6 \\
\end{array}$ & $\begin{array}{l}3 \\
2 \\
- \\
\end{array}$ & $\begin{array}{l}1 \\
3 \\
- \\
\end{array}$ & $\begin{array}{l}- \\
1 \\
-\end{array}$ \\
\hline Vaccination* & $\begin{array}{l}\text { Yes } \\
\text { No }\end{array}$ & $\begin{array}{l}23 \\
12\end{array}$ & $\begin{array}{l}4 \\
1\end{array}$ & $\begin{array}{l}1 \\
3\end{array}$ & $\begin{array}{l}- \\
1\end{array}$ \\
\hline
\end{tabular}

*vaccination against feline panleukopenia, rhinotracheitis and calicivirus infection

from noneffusive infectious peritonitis; combined infections by FIPV and FIV were demonstrated in the remaining four. Combined FIP+FeLV and FIP+FIV+FeLV infections, demonstrated in five and one cases, respectively, could not be included in the study for technical reasons.

Table 2

Clinical signs in FIP patients

\begin{tabular}{|c|c|c|c|}
\hline Sign & $\begin{array}{c}\text { Effusive form } \\
n=24\end{array}$ & $\begin{array}{l}\text { Noneffusive form } \\
n=11\end{array}$ & $\begin{array}{c}\text { Total } \\
\mathrm{n}=35\end{array}$ \\
\hline Effusion in the thoracal cavity & 4 & - & 4 \\
\hline Effusion in the abdominal cavity & 15 & - & 15 \\
\hline Effusion in the both cavities & 5 & - & 5 \\
\hline \multirow{3}{*}{$\begin{array}{ll}\text { Nutritional state } & \text { good } \\
& \text { poor } \\
& \text { cachexia }\end{array}$} & 0 & 4 & 4 \\
\hline & 10 & 1 & 11 \\
\hline & 4 & 6 & 10 \\
\hline Ischemic mucosae & 19 & 7 & 26 \\
\hline Icterus & 8 & 2 & 10 \\
\hline Hypopyon, hyphema & 0 & 3 & 3 \\
\hline Anorexia & 23 & 9 & 32 \\
\hline Lethargy & 20 & 9 & 29 \\
\hline Lymphadenopathy & 6 & 5 & 11 \\
\hline Respiratory complications & 9 & 4 & 13 \\
\hline Urogenital complications & 8 & 9 & 17 \\
\hline Vomiting & 7 & 2 & 9 \\
\hline Diarrhea & 4 & 3 & 7 \\
\hline
\end{tabular}

A significant increase in the number of segmented neutrophilic granulocytes and a decrease in the number of lymphocytes were observed in the FIP subgroups (Table 3). Moreover, the animals affected by the effusive form showed also a decrease in the number 
Table 3

Total and differential leukocyte counts $\left(\times 10^{6} / 1\right)$ in FIP patients and controls

\begin{tabular}{|c|c|c|c|c|c|}
\hline \multirow[b]{2}{*}{ Cell type } & \multicolumn{4}{|c|}{ FIP } & \multirow[b]{2}{*}{$\begin{array}{c}\text { Controls } \\
\mathrm{n}=36\end{array}$} \\
\hline & $\begin{array}{l}\text { Total } \\
\mathrm{n}=14\end{array}$ & $\begin{array}{l}\text { FIV- / FeLV- } \\
\text { effusive form } \\
\quad n=6\end{array}$ & $\begin{array}{c}\text { FIV- / FeLV- } \\
\text { noneffusive form } \\
n=4\end{array}$ & $\begin{array}{c}\text { FIV+ / FeLV- } \\
\text { effusive form } \\
n=4\end{array}$ & \\
\hline Leukocytes & $11893 \pm 5749$ & $12183 \pm 2108^{*}$ & $11400 \pm 8091$ & $11950 \pm 8358$ & $9046 \pm 3585$ \\
\hline Lymphocytes & $1446 \pm 1011^{* *}$ & $1540 \pm 1198 * *$ & $1339 \pm 1119 * *$ & $1411 \pm 869^{* *}$ & $4452 \pm 2258$ \\
\hline Neutrophils & $9783 \pm 4981^{* * *}$ & $9943 \pm 1695 * *$ & $9506 \pm 6695$ & $9819 \pm 7598$ & $3640 \pm 1926$ \\
\hline Eosinophils & $185 \pm 320^{* *}$ & $99 \pm 114 * *$ & $310 \pm 490$ & $191 \pm 382$ & $681 \pm 592$ \\
\hline Monocytes & $479 \pm 458$ & $602 \pm 407$ & $146 \pm 223$ & $529 \pm 692$ & $274 \pm 223$ \\
\hline
\end{tabular}

Statistical significance $* \mathrm{P}<0.05 * * \mathrm{P}<0.01$

of eosinophilic granulocytes. No difference was found in the proportion of monocytes when compared with the control group.

No significant differences in phagocytic activity tests (Table 4) were found between the FIP-affected and the control cats. Both spontaneous and activated chemoluminiscence was increased in the affected cats, but the difference was not significant. Marked changes in the activity of peripheral blood lymphocytes were observed in the cats affected by the effusive or noneffusive forms of FIP.

Table 4

Tests of phagocytosis in FIP patients and controls

\begin{tabular}{|c|c|c|c|c|c|}
\hline \multirow[b]{2}{*}{ Parameter } & \multicolumn{4}{|c|}{ FIP } & \multirow[b]{2}{*}{$\begin{array}{c}\text { Controls } \\
n=36\end{array}$} \\
\hline & $\begin{array}{c}\text { Total } \\
\mathrm{n}=14\end{array}$ & $\begin{array}{l}\text { FIV- / FeLV- } \\
\text { effusive form } \\
\quad n=6\end{array}$ & $\begin{array}{c}\text { FIV- / FeLV- } \\
\text { noneffusive form } \\
\mathrm{n}=4\end{array}$ & $\begin{array}{c}\text { FIV+ / FeLV- } \\
\text { effusive form } \\
n=4\end{array}$ & \\
\hline$\%$ phag $^{1}$ & $\begin{array}{l}38.8 \pm \\
20.8\end{array}$ & $50.2 \pm 16.8$ & $30.3 \pm 14.6$ & $30.3 \pm 27.2$ & $40.9 \pm 26.0$ \\
\hline $\mathrm{Cl}-$ spont $^{2}$ & $4.6 \pm 5.9$ & $6.0 \pm 8.1$ & $4.2 \pm 5.4$ & $2.7 \pm 2.3$ & $2.5 \pm 2.2$ \\
\hline $\mathrm{Cl}-\mathrm{SI}^{3}$ & $6.5 \pm 5.8$ & $8.3 \pm 6.8$ & $3.3 \pm 2.7 *$ & $6.9 \pm 6.5$ & $7.4 \pm 5.5$ \\
\hline
\end{tabular}

Statistical significance $* \mathrm{P}<0.05 * * \mathrm{P}<0.01$

${ }^{1}$ percentage of phagocyting cells

2 chemiluminiscence of resting cells

${ }^{3}$ stimulation index

The activity of lymphocytes stimulated with Con A, PHA or PWM was markedly inhibited in the lymphocyte proliferation test (Table 5). The most marked inhibition was observed in the cats affected by chronic noneffusive infectious peritonitis; nevertheless, the inhibition in the patients with the effusive form was significant as well. A marked inhibition was observed also in the cats infected by FIPV+FIV.

In general, the concentrations of total immunoglobulins and circulating immune complexes were higher in the affected cats (Table 6). Markedly increased concentrations of total immunoglobulins were found in 1 and 3 cats with the noneffusive and effusive forms, respectively. The concentration of CIC was markedly increased in 1 and 2 cats with the noneffusive and effusive forms, respectively. The differences in mean concentrations of Ig and CIC between any of the two groups and controls were insignificant. No increase was observed in the group of cats infected by FIPV + FIV. 
Table 5

Lymphocyte blastic transformation test in FIP patients and controls

\begin{tabular}{|c|c|c|c|c|c|}
\hline \multirow[b]{2}{*}{ Mitogens } & \multicolumn{4}{|c|}{ FIP } & \multirow[b]{2}{*}{$\begin{array}{c}\text { Controls } \\
n=36\end{array}$} \\
\hline & $\begin{array}{c}\text { Total } \\
\mathrm{n}=14\end{array}$ & $\begin{array}{l}\text { FIV- / FeLV- } \\
\text { effusive form } \\
n=6\end{array}$ & $\begin{array}{c}\text { FIV- / FeLV- } \\
\text { noneffusive form } \\
n=4\end{array}$ & $\begin{array}{l}\mathrm{FIV}+/ \text { FeLV- } \\
\text { effusive form } \\
\quad n=4\end{array}$ & \\
\hline Resting cells ${ }^{1}$ & $222 \pm 157$ & $221 \pm 146$ & $121 \pm 31 * *$ & $302 \pm 208$ & $298 \pm 216$ \\
\hline PHA (SI) & $1.7 \pm 2.2 * *$ & $2.6 \pm 3.2 * *$ & $1.0 \pm 0.1 * *$ & $0.8 \pm 0.2 * *$ & $7.0 \pm 7.9$ \\
\hline ConA1(SI) & $5.5 \pm 11.2 * *$ & $8.1 \pm 16.4 *$ & $1.8 \pm 0.7 * *$ & $4.6 \pm 5.0 * *$ & $33.3 \pm 35.0$ \\
\hline ConA2 (SI) & $2.5 \pm 2.5 * *$ & $2.2 \pm 2.2 * *$ & $1.8 \pm 1.1 * *$ & $3.3 \pm 3.7 * *$ & $13.6 \pm 11.6$ \\
\hline PWM (SI) & $3.6 \pm 7.1 * *$ & $5.4 \pm 10.6$ & $1.5 \pm 0.2 *$ & $2.6 \pm 1.8^{* * *}$ & $11.5 \pm 10.2$ \\
\hline
\end{tabular}

Statistical significance $* \mathrm{P}<0.05 * * \mathrm{P}<0.01$

1 counts per minute

SI - stimulation index

Table 6

Concentration of total immunoglobulins (TIg) and circulating immune-complexes (CIC) in FIP patients and controls

\begin{tabular}{|c|c|c|c|c|c|}
\hline \multirow[b]{2}{*}{ Parameter } & \multicolumn{4}{|c|}{ FIP } & \multirow[b]{2}{*}{ Controls } \\
\hline & Total & $\begin{array}{l}\text { FIV- / FeLV- } \\
\text { effusive form }\end{array}$ & $\begin{array}{c}\text { FIV- / FeLV- } \\
\text { noneffusive form }\end{array}$ & $\begin{array}{l}\text { FIV+ / FeLV- } \\
\text { effusive form }\end{array}$ & \\
\hline TIg & $\begin{array}{c}19.7 \pm 11.4 \\
n=14\end{array}$ & $\begin{array}{c}24.3 \pm 15.2 \\
n=6\end{array}$ & $\begin{array}{c}21.2 \pm 8.5 \\
n=4\end{array}$ & $\begin{array}{c}12.4 \pm 5.0 \\
n=4\end{array}$ & $\begin{array}{c}13.0 \pm 6.4 \\
n=31\end{array}$ \\
\hline $\mathrm{CIC}$ & $\begin{array}{r}46 \pm 35 \\
n=11\end{array}$ & $\begin{array}{c}53 \pm 48 \\
n=5\end{array}$ & $\begin{array}{c}38 \pm 21 \\
n=3\end{array}$ & $\begin{array}{c}41 \pm 24 \\
n=3\end{array}$ & $\begin{array}{r}30 \pm 17 \\
n=30\end{array}$ \\
\hline
\end{tabular}

The expression of surface antigens of lymphocytes was investigated in a limited set of cats (Table 7). A higher percentage of CD5+ lymphocytes and a lower percentage of CD21+ lymphocytes was observed in two cats affected by the effusive form of peritonitis. An increase in the percentage of $\mathrm{CD} 8+$ and a decrease in the percentage of CD4+, resulting in a lowering of the CD4+ : CD8+ ratio was found in one cat affected by the effusive and another one affected by the noneffusive form of peritonitis. Marked change in the CD4+ : CD8+ ratio was apparent in one cat infected by FIPV + FIV. However, the differences are inconclusive owing to the small number of tested animals.

Table 7

Lymphocyte subsets in peripheral bood of FIP patients and controls

\begin{tabular}{|lccccc|}
\hline Cat number & CD4+ $(\%)$ & CD5+ $(\%)$ & CD8+ $(\%)$ & CD21+ (\%) & CD4+/CD8+ \\
$8155(\mathrm{E})$ & 41.0 & ND & 37.2 & 5.5 & 1,1 \\
$8200(\mathrm{E})$ & 41.8 & 88.5 & 13.5 & 4.9 & 3,1 \\
$8226(\mathrm{E})$ & 57.7 & 80.7 & 15.8 & 17.2 & 3,6 \\
$8189(\mathrm{~N})$ & 16.3 & 56.7 & 35.5 & 29.2 & 0,5 \\
$8211(\mathrm{~N})$ & 35.1 & 46.8 & 15.6 & 14.0 & 2,3 \\
$8204(+\mathrm{FIV})$ & 15.1 & $\mathrm{ND}$ & 33.6 & 10.8 & 0,5 \\
$8140(+\mathrm{FIV})$ & 19.6 & $\mathrm{ND}$ & 8.9 & $\mathrm{ND}$ & 2,2 \\
Controls $(\mathrm{n}=36)$ & $38.4 \pm 8.0$ & $65.5 \pm 14.4$ & $18.5 \pm 8.8$ & $19.4 \pm 9.9$ & $2.8 \pm 1.0$ \\
\hline
\end{tabular}

$\mathrm{E}$ - effusive form $\quad \mathrm{N}$ - noneffusive form 


\section{Discussion}

The set of the 180 cats under study included $30.6 \%$ animals serologically positive for $\mathrm{FeCoV}$ infection. Although the set is too small to be regarded as a sample representative for the Czech Republic, our results are comparable with those published in other European countries and the USA and ranging from 10 to $40 \%$ (Pedersen 1976; Loeffler et al. 1978). Feline coronaviruses share a number of antigens responsible for cross-reactions in serological tests. Hence, an exact distinction between latent FIP and other feline coronavirus infections is rather difficult (Evermann et al. 1995). Typical manifestations of FIP were observed in $19.4 \%$ of the 180 cats.

FIP can affect cats of any age, but a higher sensitivity is apparent in animals younger than 2 years and particularly kittens up to the age of 1 year. Clinical FIP is observed relatively frequently in cats younger than 5 years (Weiss 1994). In our set, most of the animals positive for antibodies to $\mathrm{FeCoV}$ as well as those showing clinical signs of FIP were younger than 4 years.

No predisposition to FIP associated with sex or breed has so far been demonstrable owing to large differences in percentages of males and females and representatives of individual breeds tested in the published studies. The same applies also to our set of patients. The unusual percentages of castrated animals (25.8\% males, $21.4 \%$ females) and animals vaccinated against the common feline viral infections $(50.9 \%)$ in the subgroup of cats positive for $\mathrm{FeCoV}$ infections resulted from the fact that 20 of them were pedigree animals and were tested on request of their owners. The actual percentage of intact cats is much higher and the percentage of vaccinated cats is lower in the Czech Republic. Periodical vaccination is required only by owners of pedigree animals attending international cat shows. The percentage of cats allowed free roaming outside the house of the owner $(70.9 \%)$ corresponds to the current trend (Knotek et al. 1999). The interest in serological testing for FeLV, FIV and FeCoV has increased only recently after the publication of preliminary data on isolations of these agents in the Czech Republic (Knotek et al. 1995, 1997).

Our set included $12.8 \%$ cats positive for FeLV, 5.6\% cats positive for FIV, $1.1 \%$ cats positive for FeLV+FIV, 32.2\% cats positive for FIP+FIV, $2.8 \%$ cats positive for FIP+FeLV, and $0.6 \%$ cats positive for FIP+FIV+FeLV. The prevalence of cats positive for the FeLV antigen or antibodies to FIV corresponds to current data on feline retrovirus infections in the Czech Republic (Knotek et al. 1999), whereas no other data on the occurrence of antibodies to $\mathrm{FeCoV}$ to be compared with our results have been available.

The changes in blood cytology observed in our patients correspond to data published recently by other authors (Paltrinieri et al. 1998a) and to typical findings in patients affected by infectious peritonitis as published earlier (Rohrer et al. 1993). Paltrinieri et al. (1998a) reported a significant decrease in peripheral lymphocyte counts in FIP patients. The authors did not investigate percentages of lymphocyte subpopulations and their activities, but assume that changes in the activities of lymphocytes in FIP-positive animals are possible. Our results show alterations of at least some in vitro functions of lymphocytes in such animals. This applies particularly to the inhibition of lymphocytic activity and/or changes in the ratios of lymphocyte subpopulations. As concanavalin and phytohemagglutinin are regarded as T mitogens in cats (Schultz and Adams 1978; Rottman et al. 1996; Gun-Moore et al. 1998), the weaker responses of lymphocytes to any of the two mitogens are suggestive of effects of FIP infection on T lymphocytes. On the other hand, the weaker response to pokeweed mitogen indicates the effects on B lymphocytes.

Investigations in a larger set of patients will be necessary to decide whether the observed changes are typical of the individual clinical forms of FIP and whether the IV ${ }^{\text {th }}$ hypersensitivity type is involved in the pathogenesis (Paltrinieri et al. 1998b). Our attention in continuing studies will be paid to the dynamics of impairment and mechanisms 
controlling the activity of lymphocytes in the course of FIP infection. Gun-Moore et al. (1998) confirmed under experimental conditions the immunosuppressive character of FIP including a stepwise decrease of production of cytokines IL-2, IL-4, IL-10, IL-12, and IFN already at an early stage of infection.

Increased concentrations of immunoglobulins and circulating immune complexes were found in our set particularly in the patients suffering from the effusive form of FIP. This finding corresponds to the presumed role of activated B lymphocytes in the development of the clinical picture and morphological lesions associated with FIP (Goitsuka et al. 1987, 1988, 1990; Kipar et al. 1998), and the involvement of III $^{\text {rd }}$ hypersensitivity type in the pathogenesis (Paltrinieri et al. 1998b).

Significant lymphopenia, marked inhibition of activity of stimulated lymphocytes, and a change in the $\mathrm{CD} 4+: \mathrm{CD} 8+$ ratio were found in the cats infected by FIPV+FIV. A decrease in the number and in vitro activity of T lymphocytes and neutrophilic granulocytes can be observed in patients infected by FeLV or FIV (Mathes et al. 1978; Ackley et al. 1990) and clinical signs of other viral infections can develop in such immunologically compromised patients (Bech-Nielsen et al. 1981) including FIP (Pedersen 1983; Pedersen 1987; Reinacher 1989). We assume that the changes in the expression of the CD4 and CD8 antigens in our patients affected by dual infections were due mostly to FIV, whereas the inhibition of activity of lymphocytes resulted from FIP or from a combined effect of the two infections. The clinical pattern of FIPV+FIV infections in our patients corresponded to an advanced stage of infectious peritonitis and all the patients died or were euthanatized within a short period.

Clinical forms of FIP are associated with changes in leukocyte counts and activity including neutrophilia, lymphopenia, reduced activity of lymphocytes, and increase in the concentrations of immunoglobulins and circulating immune complexes. It is apparent that immune responses are suppressed in FIP patients and therefore immunosuppressive drugs should be avoided in the treatment.

\section{Klinická a imunologická charakteristika koček s virovou infekční peritonitidou}

Klinické projevy virové infekční peritonitidy koček (FIP) a př́tomnost protilátek proti kočičím koronavirům $(\mathrm{FeCoV})$ byly vyšetřovány u skupiny 180 hospitalizovaných i ambulantně ošetřených pacientů. Klinické projevy onemocnění byly potvrzeny u 35 koček, sérologicky bylo pozitivních 55 zviřat (30.6\%). Efúzivní a neefúzivní forma FIP byly zjištěny u 24 a 11 koček. Bez ohledu na formu infekce byly nejčastějšími projevy nechutenství, apatie, ischémie sliznic a podvýživa. Byly porovnány hematologické a imunologické parametry u 14 koček s FIP a 36 klinicky zdravých zviŕrat, u kterých nebyly prokázány protilátky proti FeCoV. U koček s efúzivní formou FIP (FIV-/FeLV-) byl zjištěn statisticky průkazný vzestup počtu neutrofilních granulocytů. U pacientů s FIP byla zaznamenána eozinopenie a statisticky průkazná lymfopenie. U koček s FIP nebyly ovlivněny parametry fagocytózy (ingesce partikulí, chemiluminiscence), výrazný byl pokles aktivity lymfocytů v testu blastické transformace (stimulace s Con A, PHA a PWM). U koček s FIP byla zjištována zvýšená koncentrace imunoglobulinů a cirkulujících imunokomplexů. U vybrané skupiny pacientů byla s pomocí průtokové cytometrie sledována exprese povrchových lymfocytárních antigenů CD4, CD5, CD8 a CD21. Výsledky naznačují narušení imunitního systému vlivem FIP. Z tohoto důvodu nepovažujeme léčbu FIP imunosupresivními preparáty za vhodnou.

\section{Acknowledgements}

The project was supported by the Grant Agency of the Czech Republic (Grant No. 524/96/0267 and partly No. 508/95/1417). The authors wish to thank Ms L. Levá, H. Kudláčková, E. Kotlářová, and P. Hořavová for competent technical assistance in immunological tests, and Dr. P. Hájková and Dr. V. Raška for technical assistance in blood 
sampling and sample processing. The authors are grateful to prof. K. Möstl (Veterinary University Vienna) for her comments to the manuscript.

\section{References}

ACKLEY, C. D., YAMAMOTO, J. K., LEVY, N., PEDERSEN, N. C., COOPER, M. D. 1990: Immunologic abnormalities in pathogen-free cats experimentally infected with feline immunodeficiency virus. J. Virol. 64: $5652-5655$

BECH-NIELSEN, S., FULTON, R.W., DOWNING, M. M., HARDY, W. D. Jr. 1981: Feline Infectious Peritonotis and Viral Respiratory Diseases in Feline Leukemia. Virus Infected Cats. J. Amer. Anim. Hosp. Assoc. 17: 759-765

EVERMANN, J.F., HENRY, C. J., MARKS, S.L. 1995: Feline infectious peritonitis. J. Amer. Vet. Med. Assoc. 206: $1130-1134$

EVERMANN, J. F., McKIERNAN, A. J., OTT, R.L. 1991: Perspectives on the epizootiology of feline enteric coronavirus and the pathogenesis of feline infectious peritonitis. Vet. Microbiol. 28: 243-255

FALDYNA, M., TOMAN, M. 1998: The effect of age on the distribution of lymphocyte and neutrophil granulocyte subsets in the peripheral blood of dog. Vet. Med. - Czech 43: 193-199

GOITSUKA, R., ONDA, C., HIROTA, Y., HASEGAWA, A., TOMODA, I. 1988: Feline interleukin 1 production induced by feline infectious peritonitis. Jpn. J. Vet. Sci. 50: 209-214

GOITSUKA, R., HIROTA, Y., HASEGAWA, A., TOMODA, I. 1987: Release of interleukin 1 from peritoneal exudate cells of cats with feline infectious peritonitis. Jpn. J. Vet. Sci. 49: 811-818

GOITSUKA, R., OHASHI, T., ONO, K., HIROTA, Y., HASEGAWA, K., KOISHIBARA, Y., FUKUI, H., OHSUGI, Y., HASEGAWA, A. 1990: Interleukin 6 activity in feline infectious peritonitis. J. Immunol. 14: $2599-2603$

GUNN-MOORE, D. A., CANEY, S. M. A., GRUFFYD-JONES, T. J., HELPS, C. R., HARBOUR, D. A. 1998: Antibody and cytokine responses in kittens during the development of feline infectious peritonitis (FIP). Vet. Immunol. Immunopathol. 65: 221-242

HÁJKOVÁ, V. 1986: Průkaz cirkulujících imunokomplexů. In: Procházková, J. - John, C. (eds): Vybrané diagnostické metody lékařské imunologie, Praha, Avicenum, 114-119 (in Czech)

HOSKINS, J. D., TAYLOR, H. W., LOMAX, T. L. 1994: Challenge trial of an intranasal feline infectious peritonitis vaccine. Feline Pract. 22: 9-13

KIPAR, A., BELLMANN, S., KREMENDAHL, J., KOHLER, K., REINACHER, M. 1998: Cellular composition, coronavirus antigen expression and production of specific antibodies in lesions in feline infectious peritonitis. Vet. Immunol. Immunopathol. 65: 243-257

KNOTEK, Z., SVOBODA, M., JELÍNEK, F., HÁJKOVÁ, P. 1995: Felinní infekční peritonitida. Proc. Annu. Confer. CSAVA, Brno 44-46 (in Czech)

KNOTEK, Z., GOJDA, M., SVOBODA, M. 1997: Diagnostika retrovirových infekcí koček v klinické praxi. Veterinárství 47: 20-22 (in Czech)

KNOTEK, Z., HÁJKOVÁ, P., SVOBODA, M., TOMAN, M., RAŠKA, V. 1999: Epidemiology of feline leukaemia and feline immunodeficiency virus infections in the Czech Republic. J. Vet. Med. B 46: 665-671

LOEFFLER, D. G., OTT, R. L., EVERMANN, J. F., ALEXANDER, J. E. 1978: The incidence of naturally occurring antibodies against feline infectious peritonitis in selected cat populations. Feline Pract. 8: 43-47

MATHES, L. E., OLSEN, R. G., HELEBRAND, L. C. et al. 1978: Abrogation of lymphocyte blastogenesis by feline leukaemia virus protein. Nature 274: 687-689

McEWAN, A. D., FISHER, E. W., SELMAN, I. E., PENHALE, W. J. 1970: A turbidity test for estimation of immune globulin levels in neonatal calf serum. Clin. Chim. Acta 27: 155-163

OLSEN, C.W. 1993: A review of feline infectious peritonitis virus: molecular biology, immunopathogenesis, clinical aspects, and vaccination. Vet. Microbiol. 36: 1-36

PALTRINIERI, S., CAMMARATA PARODI, M., CAMMARATA, G., COMAZZI, S. 1998a: Some aspects of humoral and cellular immunity in naturally occurring feline infectious peritonitis. Vet. Immunol. Immunopathol. 65: $205-220$

PALTRINIERI, S., CAMMARATA PARODI, M., CAMMARATA, G., MAMBRETTI, M. 1998b: Type IV hypersensitivity in the pathogenesis of FIPV induced lesions. J. Vet. Med. B 45: 151-159

PEDERSEN, N. C. 1976: Serologic studies of naturally occurring feline infectious peritonitis. Am. J. Vet. Res. 37: $1449-1453$

PEDERSEN, N. C. 1983: Feline infectious peritonitis and feline enteric coronavirus infections. Feline Practice 13: $5-20$

PEDERSEN, N. C. 1995: An overview of feline enteric coronavirus and infectious peritonitis virus infections. Feline Pract. 23: 7-22

PEDERSEN, N. C. 1987: Virologic an immunologic aspects of feline infectious peritonitis virus infection. Adv. Exp. Med. Biol. 218: 529-550

PEDERSEN, N. C., BOYLE, J. F. 1980: Immunologic phenomena in the effusive form of feline infectious peritonitis. Am. J. Vet. Res. 41: 868-876 
REINACHER, M. 1989: Diseases associated with spontaneous feline leukemia virus (FeLV) infection in cats. Vet. Immunol. Immunopathol. 21: 85-89

ROHRER, C., SUTER, P. F., LUTZ, H. 1993: Die Diagnostik der felinen infektiosen Peritonitis (FIP): Retrospektive und prospektive Untersuchungen. Kleintierpraxis 38: 379-389

ROTTMAN, J. B., TOMPKINS, W. A. F., TOMPKINS, M. B. 1996: A reverse transcription - quantitative competitive polymerase chain reaction (RT - qcPCR) technique to measure cytokine gene expression in domestic animals. Vet. Pathol. 33: 242-248

SCHULTZ, R. D., ADAMS, L. S. 1978: Immunologic methods for the detection of humoral and cellular immunity. Vet. Clin. North Am. 8: 721-768

VĚTVIČKA, V., FORNUSEK, L., KOPEČEK, J. 1982: Phagocytosis of human blood leukocytes: a simple micromethod. Immunol. Lett. 5: 97-100

WEISS, R. C., DODDS, W. J., SCOTT, F. W. 1980: Disseminated intravascular coagulation in experimentally induced feline infectious peritonitis. Am. J. Vet. Res. 41: 663-671

WEISS, R. C. 1994: Feline infectious peritonitis and other coronaviruses. In: Sherding, R. G. (ed): The Cat: diseases and clinical management, 2. ed., Churchill Livingstone Inc. 449-477

WOLFE, L. G., GRIESEMER, R. A. 1966: Feline infectious peritonitis. Path. Vet. 3: 255-270 